Весна Р. Манојловић Николић

Универзитет у Новом Саду

Филозофски факултет

Одсек за историју

mn.vesna.ns@gmail.com
Оригинални научни рад

примљено: 1. јул 2011

прихваћено: 1. октобар 2011

\title{
СРЕДЊОВЕКОВНИ НАЛАЗИ РАОНИКА И ПРИКАЗИ РАЛА НА ДЕЧАНСКИМ ФРЕСКАМА*
}

Сажетак: У раду је представљена једна врста симетричних раоника са средњовековних локалитета у Србији, који су према условима налаза и аналогијама опредељени у период 10-13. века. Симетрични раоници су део справа за орање, рала. Према етнографским подацима реч је о двостраним ралима. Њихов изглед познат нам је и са живописа манастира Дечани, који нам даје не само ликовни већ и хронолошки податак о времену коришћења оваквих рала. Дечанске фреске су углавном настале у периоду 1338/91343. године, а у потпуности је осликавање завршено до јесени 1347. а најкасније августа 1348. године. Истом периоду припадају и подаци из Дечанске хрисовуље краља Душана. Помињање рала познато нам је и у српском преводу византијског Земљорадничког закона. Археолошке податке о раонику и слику о изгледу двостраног рала допунили смо реконструкцијама на основу етнолошких истраживања и ликовним представама са дечанских фрески. Сагледавањем и анализом изложеног, можемо рећи да је рало веома дуго било основна справа за орање на територији Србије у средњем веку, а да се земљорадњом бавио највећи део становништва.

Кључне речи: средњовековно оруђе, раоник, рало, живопис, Дечани.

Од најранијих периода човек је користио природна богатства, а плодност тла допринела је развоју многих пољопривредних грана, што је било у вези и са коришћењем разноврсног алата, оруђа. Тако је „алат“ налажен у природи у почетку употребљаван у изворном облику, каменом је мрвљено зрневље, а дрветом и рогом копана земља. Временом је те природне облике човек почео да прилагођава својим потребама, да их обрађује. Проналажење, експлоатација и прерада руда, пре свега гвожђа, довели су до производње оруђа које је умногоме и до данас, преко римског, византијског и средњовековног, сачувало сличан облик.

Оруђе од гвожђа, неатрактивног изгледа, склоно брзом пропадању је у мањој мери привлачило пажњу истаживача у односу на друге археолошке налазе. Често је из таме земље прелазило у таму музејских кутија и депоа. За разлику од ранијих периода, у последњој деценији коментарисани су, типолошки и каталошки 
обрађени археолошки налази средњовековног оруђа са територије Војводине и општина Смедерево и Пожаревац. ${ }^{1}$ Значајан допринос проучавању оруђа од гвожђа дао је и аутор ових редова, вођен вештином и ненаметљивошћу професора Александра Јовановића. ${ }^{2}$

За тему овог прилога од значаја су радови у којима се разматра оруђе искључиво одређене функције, односно пољопривредно оруђе или чешће називано оруђе за обраду земље. Изучавање земљорадње на простору средњовековне Србије, пољопривредног оруђа и посебно справа за орање, рала и плуга, било је предмет како историјских тако и етнографска истраживања. ${ }^{3}$ Средњовековна оруђа за земљорадњу можемо да разликујемо према начину употребе. Једној групи би припадало оруђе за чије је коришћење била потребна само људска снага, а другој она која су се користила уз помоћ и сточне запреге, а то су рало и плуг. Рало као справа за орање претходило је употреби плуга. Основни делови рала су: раоник (лемеш), гредељ (оје), плаз на који је причвршћен раоник и ручица. ${ }^{4}$ Симетрични раоник је карактеристичан за рало. Он је хоризонтално положен на земљу преко плаза и подсеца је тако да она пада на обе стране од раоника. Плуг је сложеније оруђе од рала и његови делови су: гредељ (оје), плаз, раоник (лемеш), две ручице, цртало (предње сечиво), козлац, даска, а може да има и ораћа колица. ${ }^{5}$ Асиметрични раоник је део плуга. Има облик приближно правоуглог троугла, чија је најдужа страна (хипотенуза) оштрица која сече земљу. Цртало или предње сечиво подсеца земљу и обележава ширину коју ће раоник да захвати. Осим раоника једини, метални делови ових справа су још цртало и ланци за повезивање греде са колицима, док су остали делови били од дрвета. Раоници од гвожђа су веома дуго у употреби, од латенског периода, али сматра се да су им претходили дрвени, коришћени још у бронзаном добу. ${ }^{6}$

На основу до сада познатих резултата археолошких истраживања на територији Србије, могли смо да издвојима 49 налаза раоника из периода 9-16. века, од тога 43 симетрична и свега шест асиметричних. ${ }^{7}$ Овом приликом говоримо само

\footnotetext{
* Рад је настао као фазни резултат републичког пројекта број 177002 под називом Војвођански простор у контексту европске историје.

1 Марин Брмболић, Средњовековна оруђа од гвожђа у Војводини, Панчево 2000; Млађан Цуњак, Средњовековни предмети од гвожћа са територије подунавског и браничевског округа, Смедерево 2001. ${ }^{2}$ Весна Манојловић-Николић, Средњовековно оруђе од гвожђа у Србији, Нови Сад 2010.

${ }^{3}$ Милош Благојевић, Земљорадња у средњовековној Србији, Београд 1973; Branimir Bratanić, Plug i ralo, Slovenski etnograf V, Ljubljana 1952, 208-236; Исти, Ораће справе централног дијела Балканског полуострва, Зборник етнографског музеја, Београд 1953, 42-57; Isti, Nešto o starosti pluga kod Slovena, Zbornik radova Filozofskog fakulteta u Zagrebu II, Zagreb 1954, 277-306; Иван Чакан Алатке и оруђа за орање: дрвени плугови у музејима Војводине, Нови Сад 2005.

${ }^{4}$ М. Благојевић, нав. дело, 37.

${ }^{5}$ Исто, 41.

${ }^{6}$ Ю. А. Краснов, Древние и средневековые рала Восточной Европе, Советская Археология 3, Москва 1982, 66, Рис. 2/1, 2; Ивана Поповић, Античко оруће од гвожђа у Србији, Београд 1988, 99.

${ }^{7}$ Раоници са средњовековних локалитета на територији Србије су на основу облика разврстани у четири типа, а њихово датовање је извршено према условима налаза, где је то било могуће, и аналогијама; вид. В. Манојловић-Николић, нав. дело, 106-125.
} 
о оним раоницима које препознајемо и на дечанским фрескама. То је једна врста симетричних двостраних раоника, нешто мањег тела троугаоног облика, са дугачким масивнијим трном којим је причвршћиван на плаз рала. Позната су нам само три таква раоника: из околине Смедерева (сл. 1/a), са локалитета Pontes Трајанов мост (сл. 1/б) и из Поморавља, локалитет Јошанички Прњавор (сл. 1/в). ${ }^{8}$ Како су раоници из Смедерева и Јошаничког прњавора случајни налази, према аналогијама са бугарских налазишта опредељени су у $10-13$. век. ${ }^{9}$ Раоник са локалитета Pontes - Трајанов мост потиче из млађег средњовековног слоја 10-11. века. $^{10}$

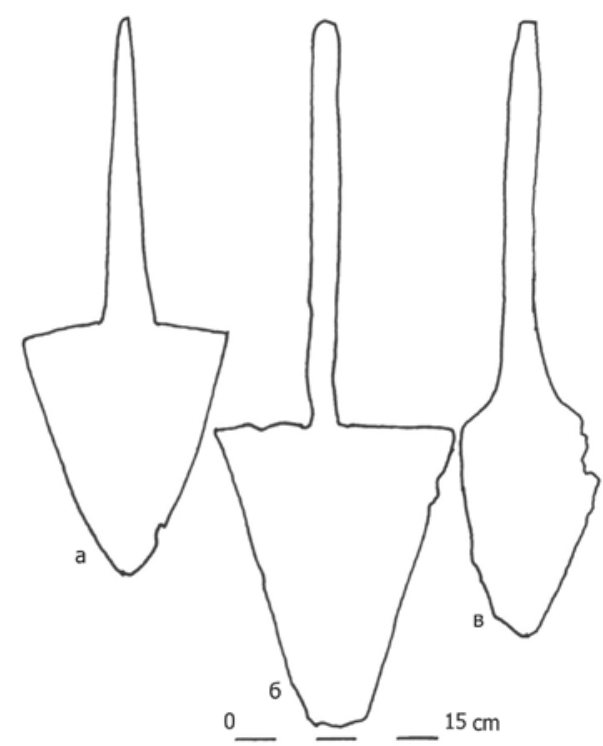

Слика 1

Симетрични раоници:

а) Смедерево; б) Pontes-Трајанов мост; в) Јошанички Прњавор

(В. Манојловић-Николић, Средњовековно оруђе од гвожђа у Србији, Нови Сад 2010, Т. 27/264-266)

Симетрични раоници припадају ралу за чију реконструкцију су незаобилазни резултати етнографских истраживања, с обзиром да његови дрвени делови нису сачувани у археолошкој грађи. Темеље савременим изучавањима рала и плуга поставио је средином прошлог века Б. Братанић, користећи резултате како

\footnotetext{
${ }^{8}$ В. Манојловић-Николић, нав. дело, 113, 115, 116, 124, Т. 27.

${ }^{9}$ Йорданка Чангова, Средновековни оръудия на труда в България, Известия на Археологически, институт XXV, София 1962, 22, Обр. 3/1, Обр. 4; Иста, Средновековното селище над тракийския град Севтополис, XI-XIV век, София 1972, 38, Обр. 23, 24; Стоян Витляанов, Особености на някои земеделски оръдия на труда в средновековна Бялгария, Плиска-Преслав, Шумен 1992, 232, Обр. 1/1-4.

${ }^{10}$ Документација Археолошког института у Београду за локалитет Pontes - Трајанов мост.
} 
етнолошких тако и археолошких истраживања. ${ }^{11}$ На основу конструктивних елемената сврстао их је у три групе: двострана, тространа и четворострана рала. ${ }^{12}$ Раоници дати у овом раду одговарају двостраним ралима (сл. 2).

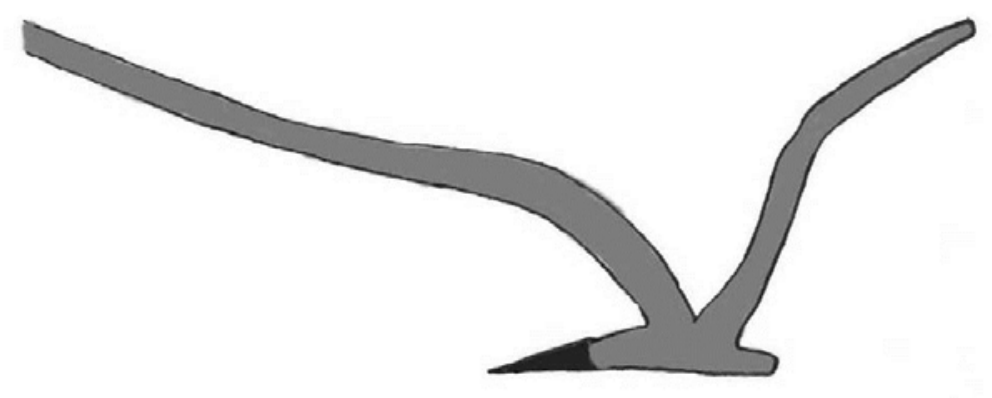

Слика 2

Двострано рало

(B. Bratanić, Oraće sprave u Hrvata, Zagreb 1939, sl. 39)

Важан значај има и средњовековни зидни живопис као извор за проучавање оруђа. Ликовне представе рала познате су нам на три фреске у Дечанима. ${ }^{13}$ На једној, Приношење жртве Каина и Авеља (сл. 3), дати су Адамови синови који приносе жртву Богу. У доњем делу фреске приказан је Авељ међу стадом оваца, а десно од њега Каин оре земљу ралом. У горњем делу фреске представљено је приношење жртве на каменим олтарима: лево Авељ приноси јагње, а десно Каин пшеницу. Авељева жртва је прихваћена, што је приказано зраком са неба, док се Каин љутито окреће од олтара због неприхватања његове жртве. ${ }^{14}$ У овој сцени треба обратити пажњу како је насликано рало чију запрегу чине два вола у јарму. Између волова се налази оје које је причвршћено за јарам, а при доњем крају се повија и спушта до лука који заклапају ручица и плаз. Плаз је потпуно покривен пренаглашено великим раоником. Троугаони раоник, са подужим усадником који пролази кроз оје и ручицу, сличан је раоницима датим у овом раду док рало, по конструкцији, одговара двостраним ралима. Сликар је веома јасно нагласио

\footnotetext{
${ }^{11}$ Branimir Bratanić, Oraće sprave u Hrvata, Zagreb 1939; Isti, Plug i ralo, Slovenski etnograf V, 208-236; Исти, Ораће справе централног дијела Балканског полуострва, Зборник етнографског музеја, Београд 1953, 42-57.

${ }^{12}$ B. Bratanić, Oraće sprave u Hrvata, 20, 21.

13 Пространа дечанска црква украшена је живописом кога чине многобројни циклуси приказани одређеним редоследом. Историјат осликавања, детаљни описи и анализа композиција и сцена подробно су дати још у првој половини прошлог века: Владимир Петковић, Дечани I и II, Београд 1941, и у најновијој монографији о манастиру Дечани: Бранислав Тодић, Милка Чанак-Медић, Манастир Дечани, Београд 2005, 325-513.

${ }^{14}$ В. Петковић, нав. дело, 48, Т. CCLV; Б. Тодић, М. Чанак-Медић, нав. дело, 346, сл. 267.
} 
материјал од кога је рало направљено, раоник од метала, а сви остали његови делови су од дрвета.

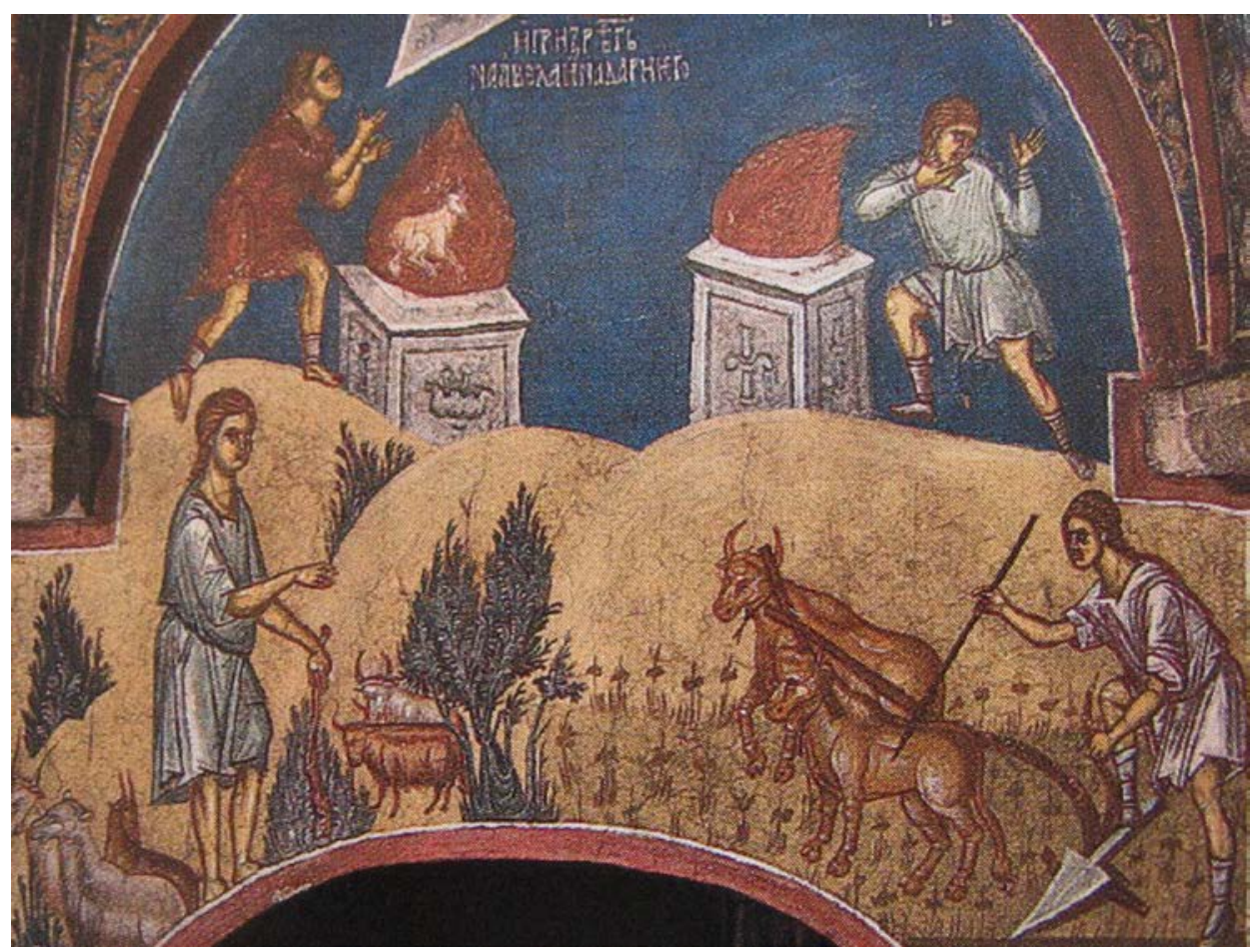

Слика 3

Приношење жртве Каина и Авеља

(Б. Тодић, М. Чанак-Медић, Манастир Дечани, Београд 2005, сл. 267)

На другој дечанској фресци која приказује сцене из пакла, за нас је занимљив део на коме је насликан крадљивац. ${ }^{15}$ Приказан је један грешник, потпуно наг, како виси док су му руке везане на леђа. О врат му је обешен тежак воденични камен, а о ноге везано рало (сл. 4). Десно од грешника стоји натпис Ко украде туђу юиву. И на овој фресци је представљен исти тип раоника и двострано рало, с том разликом да је плаз јасно наглашен, а метални продужетак раоника учвршћен је помоћу два дрвена заглавка.

\footnotetext{
${ }^{15}$ В. Петковић, нав. дело, 55, Т. CCLXXIX.
} 


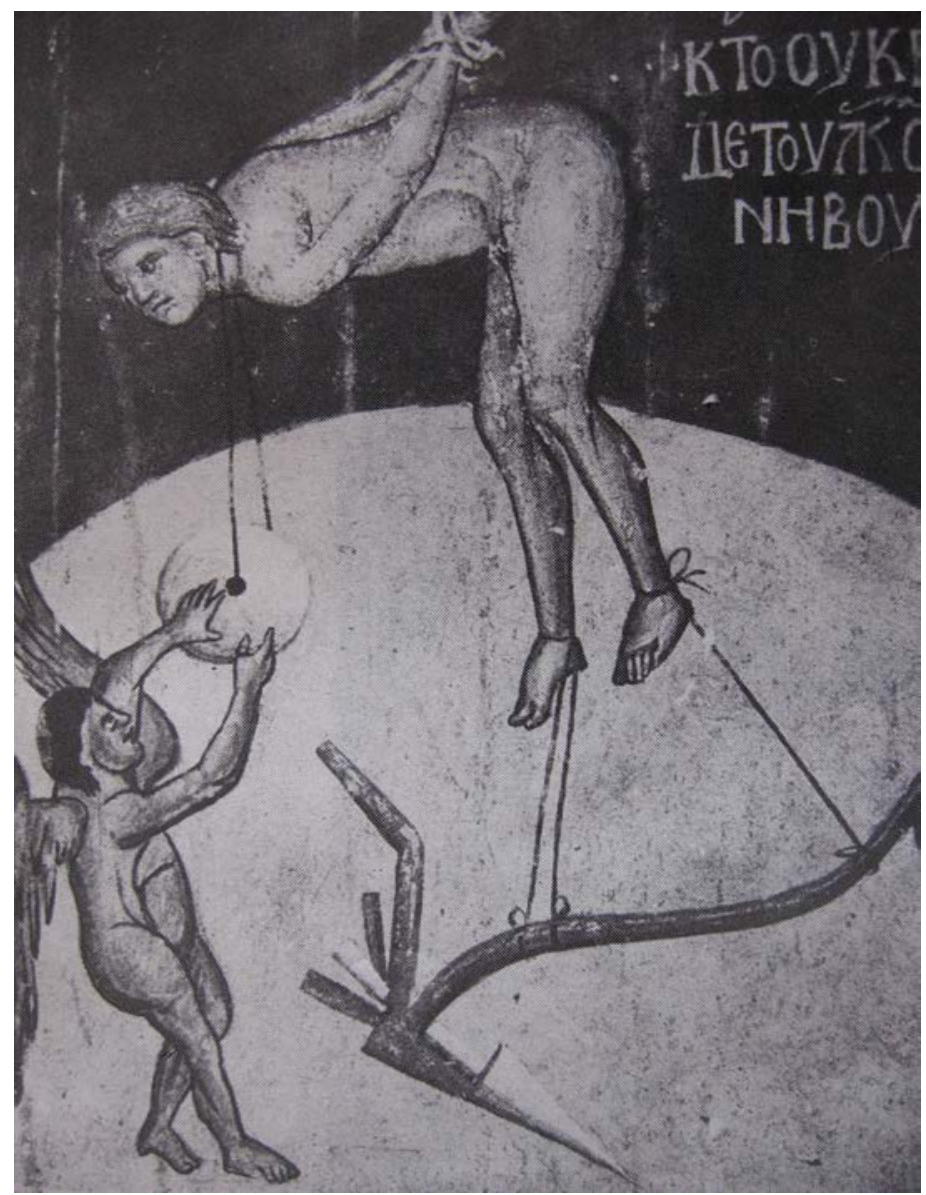

Слика 4

Страшни суд, детаљ Ко украде туђу њиву

(В. Петковић, Дечани I и II, Београд 1941, Т. CCLXXIX)

Трећа фреска из Дечана приказује Светог Ђорђа како оживљује вола једног сељака, Свети Ђорђе оживљује Гликеријевог вола. ${ }^{16}$ Веома лепо су насликана два вола од којих један лежи, а други се подиже, док је рало само делимично приказано. Наиме, види се јарам и оје и само део раоника троугаоног облика без горњег, ширег дела и продужетка којим се учвршћује на плаз. На основу приказаног дела раоника можемо рећи да припада истом типу као и раоници на претходним фрескама, а

\footnotetext{
${ }^{16}$ Исто, 4, 5, Т. CXXVIII.
} 
вероватно је да се ради такође о двостраном ралу. Све три справе за орање приказане на дечанским фрескама одговарају двостраном ралу, како су показала истраживања етнолога, на шта указује то што немају козлац и имају оје, а не гредељ. $^{17}$

Живопис Дечана нам, поред археолошких налаза, пружа још један како ликовни тако и хронолошки податак о ралу и његовом металном делу, раонику као једино сачуваном у археолошкој грађи. Дечанске фреске су углавном настале у периоду 1338/9-1343. године, а у потпуности је осликавање завршено до јесени 1347. а најкасније августа 1348 . године. ${ }^{18}$ Рало је тада било већ одомаћена справа за орање, што делом показују и археолошки налази. ${ }^{19}$ Истом периоду припадају и историјски подаци о ралу. У Дечанској хрисовуљи краља Душана помиње се реч „ралије“, што се свакако доводи у најтешњу везу са ралом и означава да је посао који се обавља њиме тако називан. ${ }^{20}$ Писани податак о ралу као справи за орање сачуван је и у српском преводу византијског Земљорадничког закона. ${ }^{21}$

Иако је земљорадња била основна пољопривредна делатност на нашем простору, познат нам је релативно мали број раоника. Разлог томе свакако треба тражити у степену истражености средњовековних локалитета, а често није ни било могуће утврдити првобитни изглед тих предмета, увелико промењених корозијом. То се посебно односи на раонике дате у овом раду. Међутим, такође симетрични раоници, двостраног сечива и троугаоног мање или више издуженог тела, али сасвим другачијег продужетка, врата којим се учвршћује на плаз су знатно бројнији. $^{22}$ Археолошке податке о раонику и слику о изгледу двостраног рала допунили смо реконструкцијама на основу етнолошких истраживања и ликовних представа са дечанских фрески. Уз то, примећујемо, да иако се у историјским подацима плуг помиње оквирно када и рало, он није приказиван на фрескама, за разлику од рала. ${ }^{23}$ Можемо рећи да је рало веома дуго било основна справа за орање на територији Србије у средњем веку, а да се земљорадњом бавио највећи део становништва. Такође, не треба занемарити ни чињеницу да је мотика, као јефтиније и за израду једноставније оруђе, била приступачнија сиромашнијим сеоским домаћинствима.

\footnotetext{
${ }^{17}$ B. Bratanić, Oraće sprave u Hrvata, 20,21.

${ }^{18}$ Б. Тодић, М. Чанак-Медић, нав. дело, 326-328.

${ }^{19}$ Овде мислимо не само на тип раоника који је у раду приказан и заступљен малим бројем налаза, већ и на остале типове раоника који су нам познати са археолошких истраживања средњовековних локалитета, вид. В. Манојловић-Николић, нав. дело, 106-125.

${ }^{20}$ М. Благојевић, нав. дело, 50.

${ }^{21}$ Ђорђе Сп. Радојчић, Српски рукопис земљорадничког закона, Зборник радова византолошког института 3, Београд 1955, 25.

${ }^{22}$ В. Манојловић-Николић, нав. дело, 106-113, 115, 121-123, Т. 24-26.

23 Асиметрични раоници, карактеристични за плуг, заступљени су са свега неколико налаза који су датовани 14-16. века, вид. В. Манојловић-Николић, нав. дело, 113, 114, 125, Т. 28. Помињање плуга забележено је у повељи манастира Св. Стефана у Бањској крајем друге деценије 14. века, вид. Стојан Новаковић, Законски споменици српских држава средњега века, Београд 1912, 625, и у грађи Дубровачког архива скраја 14. и из 15. века, вид. М. Благојевић, нав. дело, 46, 47, нап. 81, 84.
} 
Извори и литература:

Благојевић, М., Земљорадња у средњовековној Србији, Београд 1973.

Bratanić, B., Oraće sprave u Hrvata, Zagreb 1939.

Bratanić, B., Plug i ralo, Slovenski etnograf V, Ljubljana 1952.

Братанић, Б., Ораће справе централног дијела Балканског полуострва, Зборник етнографског музеја, Beograd 1953.

Bratanić, B., Nešto o starosti pluga kod Slovena, Zbornik radova Filozofskog fakulteta II, Zagreb 1954.

Брмболић, М., Средњовековна оруђа од гвожђа у Војводини, Панчево 2000.

Краснов, Ю. А., Древние и средневековые рала Восточной Европе, Советская Археология 3, Москва 1982.

Манојловић-Николић, В., Средњовековно оруђе од гвожђа у Србији, Нови Сад 2010.

Новаковић, С., Законски спомениии српских држава средњега века, Београд 1912.

Петковић, В., Дечани I и II, Београд 1941.

Поповић, И., Античко оруђе од гвожђа у Србији, Београд 1988.

Радојчић, Ђ. Сп., Српски рукопис земљорадничког закона, Зборник радова византолошког института 3, Београд 1955.

Тодић, Б., Чанак-Медић М., Манастир Дечани, Београд 2005.

Цуњак, М., Средњовековни предмети од гвожђа са територије подунавског и браничевског округа, Смедерево 2001.

Чакан, И., Алатке и оруђа за орање: дрвени плугови у музејима Војводине. Нови Сад 2005.

Чангова, Й., Средновековни оръудия на труда в България, Известия на Археологически, институт XXV, София 1962.

Чангова, Й., Средновековното селище над тракийския град Севтополис, XI-XIV век, София 1972. 


\title{
MEDIEVAL ARTIFACTS OF A PLOUGHSHARE AND THE IMAGES OF THE PLOUGH ON DEČANI FRESCOS
}

\begin{abstract}
Summary
Most of the population in the territory of Serbia dealt with agriculture in the Middle Ages. An important tool for plowing was the plough. Its main parts were: ploughshare, disc coulter, and mouldboard, which was attached to a share and a handle. All parts were made of wood, except the share, which was made of iron.

On this occasion, there have been selected only those archaeological artifacts of the plough which could be recognized on the frescoes of Dečani. It's a kind of symmetrical two-sided plough with a slightly smaller body of triangular shape, with a long massive thorn. Only three such ploughshares are known: from around Smederevo (Fig. 1 / a), from the site Pontes - Trajan's Bridge (Fig. 1 / b), and from the Morava region, the site of Jošanički Prnjavor (Fig. 1/v). Since the ploughs from Smederevo and Jošanički Prnjavor sites were found accidentally, according to the analogies with the Bulgarian sites, they originated from the period 10-13 century. The ploughs from the site Pontes - Trajan originated from the early medieval layers of 10 - 11 century. Medieval wall paintings are very important as a source for studying the tools. Fine performances of the plough are known to us from three frescos in Decani: Sacrifice of Cain and Abel (Fig. 3), Who steals someone else's field (Fig. 4) and St. George resurrects Glikerije's ox. Ploughshare displayed on the Dečani frescoes are similar to those described in this paper, while the ploughs, by their construction, are appropriate to two-sided ploughs. (Fig. 2). Besides the archaeological findings, the frescoes of Dečani provide visual and chronological information on the plough and its metal part, the ploughshare, which was the only preserved among the archaeological artifacts. Dečani frescos were mostly from the period 1338/9-1343, and their painting was fully completed in 1347/8. The historical data on the plough belong to the same period. The Dečani charter of King Dušan mentioned the word "ralije (plough)". A written description of the plough as a tool for plowing was preserved in the Serbian translation of the Byzantine Agricultural Law.

Based on archaeological findings of symmetrical ploughs and the art performances of the plough, as well as based on historical data, it could be said that the plough was in use for a very long time, and that most of the population were farmers.
\end{abstract}

Keywords: medieval tool, ploughshare, plough, painting, Dečani 